\title{
UPAYA MENINGKATKAN HASIL BELAJAR IPS TENTANG PERISTIWA PENTING YANG PERNAH DI ALAMI MENGGUNAKAN METODE DEMONSTRASI MELALUI MEDIA GAMBAR
}

\author{
Dede Rusmiati \\ Nim. 817889579 \\ Email : Dederusmiati057@Gmail.Com
}

\begin{abstract}
ABSTRAK
Penelitian ini dilakukan di SDN Harjamukti 2 Kecamatan Cimanggis Kota Depok kelas 1 yang berjumlah 31 peserta didik. Tujuan penelitian ini untuk meningkatkan hasil belajar dan motivasi belajar peserta didik pada mata pelajaran Ilmu Pengetahuan Sosial (IPS) tentang peristiwa penting yang pernah di alami dengan menggunakan metode demonstrasi melalui media gambar. Dalam pelaksanaan pembelajaran prasiklus dengan KKM 70 di dari jumlah 31 peserta didik diperoleh hasil rerata peserta didik 55,81 dan peserta didik yang mencapai KKM 14 atau 45.16\% Sedangkan mlalui pengamatan peserta didik yang dapat menjawab pertanyaan guru hanya ada 14 (45.16\%). Siklus 1 hasil rerata peserta didik 67,58 yang belum mencapai KKM berjumlah 15 peserta didik atau $48.39 \%$. Melalui data pengamatan peserta didik yang dapat menjawab pertanyaan guru hanya ada 15 (48.39\%) Dalam pelaksanaan pembelajaran siklus 2 diperoleh hasil rerata peserta didik 88,55 peserta didik yang mencapai KKM berjumlah 29 orang atau 93.5\% sedangkan data pengamatan peserta didik yang dapat menjawab pertanyaan guru berjumlah 28 orang peserta didik atau 90.32\%. Penerapan metode demonstrasi melalui Media Gambar telah memberikan pengaruh yang sangat baik dengan meningkatkan prestasi belajar dan motivasi peserta didik.
\end{abstract}

Kata-kata kunci: hasil belajar IPS, Metode Eksperimen . Media Pembelajaran

\section{PENDAHULUAN}

\section{A. Latar Belakang Belakang Masalah}

Ilmu Pengetahuan Sosial (IPS) merupakan mata pelajaran yang memiliki peranan penting dalam membentuk warga negara yang baik. Ada tiga tujuan membelajarkan IPS kepada peserta didik, yaitu agar setiap peserta didik menjadi warga negara yang baik, melatih peserta didik berkemampuan berpikir matang untuk menghadapi dan memecahkan masalah sosial, dan agar peserta didik dapat mewarisi dan melanjutkan budaya bangsanya.

Untuk itu maka pretasi belajar belajar dan pemahaman peserta didik pada mata pelajaran IPS harus baik, Akan tetapi berdasarkan pengamatan 
hasil observasi penelitian di Sekolah Dasar Negeri (SDN) Harjamukti 2 Kecamatan Cimanggis Kota Depok kelas 1 Mata Pelajaran IPS tentang "Peristiwa Penting yang Dialami" dengan Kriteria Ketuntasan Maksimum (KKM) 70 diperoleh rata-rata peserta didik 55,81 dengan perincian 14 orang peserta didik dari 31 atau $54.84 \%$ tidak mencapai KKM, dan 17 orang peserta didik atau $45.16 \%$ mencapai KKM. Dengan demikian, peserta didik tidak mampu menerima informasi yang disampaikan sesuai dengan tujuan yang telah di tetapkan oleh guru dengan merujuk pada tidak tercapainya KKM Mata Pelajaran IPS

Ketidakberhasilan tersebut disebabkan karena beberapa faktor dan kondisi di lingkungan belajar, baik dari faktor peserta didik, sarana dan prasarana, maupun dari kompetensi guru itu sendiri, dalam menyajikan metode yang lebih berfariasi dalam proses pembelajaran. Sehingga kemampuan guru di tuntut dalam mengelola kelas agar suasana belajar siswa selalu aktif dan produktif dengan metode mengajar yang direncanakan. Selain itu guru harus memiliki pemahaman yang baik mengenai materi ke-IPS-an, metode pembelajaran, dan sistem penilaian, serta tujuan-tujuan pembelajaran IPS. Faktor lain rendah nilai siswa adalah mata pelajaran IPS juga diasumsikan sebagai pelajaran yang tidak menarik karena hanya bersifat hafalan. Asumsi yang keliru itu bahkan terjadi pada kalangan guru sendiri,

Tidak adanya media pembelajaran yang digunakan oleh guru dalam proses pembelajaran. Hal ini dikarenakan media memiliki andil untuk menjelaskan hal-hal yang abstrak dan menunjukan hal-hal yang tersembunyi. Ketidakjelasan atau kerumitan materi pembelajaran dapat dibantu dengan menghadirkan media sebagai perantara. Bahkan dalam hal-hal tertentu media dapat mewakili kekurangan guru dalam mengkomunikasikan materi pelajaran. Namun perlu diingat bahwa peranan media tidak akan terlihat apabila penggunaanya tidak sejalan dengan esensi tujuan pengajaran yang telah dirumuskan. Karena itu tujuan pengajaran harus dijadikan sebagai pangkal acuan untuk menggunakan media. Manakala diabaikan maka media 
bukan lagi sebagai alat bantu pengajaran tetapi sebagai penghambat dalam pencapaian tujuan secara efektif dan efisien.

Oleh karena itu untuk memperbaiki hasil belajar peserta didik khususnya pada pelajaran IPS Kelas 1 Di SDN Harjamukti 2 perlu adanya Penelitian Tindakan Kelas (PTK) di dalamnya. Berdasarkan latar belakang masalah di atas, peneliti tertarik untuk mengadakan penelitian dengan judul “Meningkatkan Hasil Belajar Ilmu Pengetahuan Sosial Tentang Peristiwa Penting yang Pernah di Alami dengan Menggunakan Metode Demonstrasi Melalui Media Gambar Pada Peserta Didik Kelas 1 Di SDN Harjamukti 2 Kecamatan Cimanggis Kota Depok”.

\section{Identifikasi Masalah}

Berdasarkan dari latar belakang masalah tersebut, maka dapat di identifikasi masalah sebagai berikut :

a. Rendahnya hasil belajar peserta didik pada mata pelajaran IPS hal ini dilihat dari hasil rerata peserta didik hanya

b. Rendahnya minat belajar peserta didik.

c. Banyak peserta didik yang sulit memahami materi

d. Peserta didik kurang termotivasi dalam pembelajaran IPS ini dengan materi peristiwa penting yang pernah di alami.

e. Peserta didik kurang fokus pada saat pembelajaran berlangsung.

f. Peserta didik sangat pasif dalam menerima pelajaran ini.

\section{Analisa Masalah}

Berdasarkan identifikasi masalah di atas maka, di ketahui penyebab dari masalah ini adalah :

a. Guru tidak menggunakan metode pembelajaran dan teknik pembelajaran yang bervariasi dan efektif yang sesuai secara maksimal sehingga peserta didik mengalami kesulitan dan mengakibatkan menurunnya minat peserta didik dan pada akhirnya menurunnya hasil belajar. 
b. Guru tidak menggunakan media pembelajaran yang sesuai secara maksimal sehingga tidak terciptanya suasana pembelajaran yang kondusif, dan menyenangkan bagi peserta didik

c. Guru kurang memberikan motivasi pada saat pembelajaran berlangsung sehingga peserta didik tidak tertarik pada pelajaran IPS

d. Guru kurang memberikan kesempatan kepada peserta didik untuk bertanya dan melibatkan peserta didik dalam materi ini.

e. Guru jarang mengadakan dan reward kepada umpan balik secara langsung selama pembelajaran, sehingga peserta didik tidak aktif.

\section{Alternatif dan Prioritas Pemecahan Masalah}

Keberhasilan dari suatu proses pembelajaran untuk memenuhi keinginan dalam peningkatan kualitas di tentukan beberapa faktor, salah satu di antaranya adalah pemilihan media pembelajaran yang tepat untuk menunjang peningkatan minat belajar peserta didik yaitu dengan cara :

a. Guru sebaiknya menggunakan metode pembelajaran dan teknik pembelajaran yang bervariasi dan efektif

b. Guru sebaiknya menggunakan media pembelajaran yang sesuai secara maksimal sehingga terciptanya suasana pembelajaran yang kondusif, dan menyenangkan bagi peserta didik

c. Guru harus memberikan motivasi pada saat pembelajaran berlangsung sehingga peserta didik tertarik pada pelajaran IPS

d. Guru harus memberikan kesempatan kepada peserta didik untuk bertanya dan melibatkan peserta didik dalam materi ini.

e. Guru harus mengadakan reward dan umpan balik secara langsung selama pembelajaran, sehingga peserta didik tidak aktif.

\section{B. Rumusan Masalah}

Berdasarkan identifikasi dan analisis masalah yang dipaparkan di atas, dapat dirumuskan masalah adalah"Bagaiaman meningkatkan hasil belajar ilmu pengetahuan sosial tentang Peristiwa Penting yang Pernah di Alami dengan menggunakan metode demonstrasi dan media gambar pada peserta didik kelas 1 di SDN Harjamukti 2 Kecamatan Cimanggis Kota Depok 


\section{Tujuan Penelitian Perbaikan Pembelajaran}

Berdasarkan uraian dari rumusan masalah setiap kegiatan penelitian yang di lakukan adalah untuk meningkatkan hasil belajar Ilmu Pengetahuan Sosial tentang peristiwa penting yang pernah di alami dengan menggunakan metode demonstrasi dan media gambar pada peserta didik kelas 1 di SDN Harjamukti 2 Kecamatan Cimanggis Kota Depok.

Tujuan Penelitian Perbaikan Pembelajaran dapat diuraikan sebagai berikut

1. Untuk meningkatkan hasil belajar IPS tentang peristiwa penting yang pernah di alami dengan menggunakan metode demonstrasi pada peserta didik kelas 1 di SDN Harjamukti Kecamatan Cimanggis Kota Depok?

2. Untuk meningkatkan hasil belajar ilmu pengetahuan sosial tentang peristiwa penting yang pernah di alami dengan menggunakan media gambar pada peserta didik kelas 1 di SDN Harjamukti Kecamatan Cimanggis Kota Depok?

3. Untuk mengetahui penyebab peserta didik yang tidak mampu memahami materi tentang peristiwa penting yang pernah di alami.

4. Untuk meningkatkan kreatifitas guru dalam melaksanakan pembelajaran IPS untuk materi tentang peristiwa penting yang pernah di alami.

\section{Manfaat Penelitian Perbaikan Pembelajara}

Manfaat penelitian perbaikan pembelajaran di susun dalam rangka peningkatan mutu pendidikan dan memberikan manfaat yang positif bagi berbagai pihak :

1. Bagi peserta didik

a. Dapat memotivasi peserta didik untuk belajar lebih giat khususnya dalam pembelajaran IPS sehingga mengurangi kebosanan dalam belajar.

b. Dapat mengembangkan rasa kebersamaan dan kerja sama peserta didik dengan peserta didik lain.

c. Membiasakan peserta didik berani tampil dan percaya diri. 
2. Bagi Guru

a. Memperbaiki pembelajaran yang di kelola.

b. Dapat mengetahui masalah - masalah dan kesulitan yang di hadapi peserta didik dalam pembelajaran IPS.

c. Dapat meningkatkan kualitas pembelajaran.

3. Bagi sekolah

a. Hasil laporan penelitian ini dapat di gunakan sebagai tambahan referensi bagi rekan guru yang akan mengadakan penelitian.

b. Dapat memberikian perbaikan mutu pelajaran IPS di kelas 1 SDN Harjamukti 2.

\section{KAJIAN PUSTAKA}

\section{A. Hasil Belajar Ilmu Pengetahuan Sosial}

\section{Hasil Belajar}

David R. Shaffer, seperti yang dikutip oleh Rasyid (2000:86), mengemukakan bahwa belajar adalah proses perubahan perilaku yang relatif menetap sebagai hasil pengalaman-pengalaman atau praktek. Sedangkan meneurut N.L Gage D.C. dalam Rasyid (1983:73), berpendapat bahwa belajar merupakan suatu proses dimana suatu organisme berubah perilakunya sebagai akibat pengalaman. Menurut Winkel (1990:66), belajar adalah suatu aktifitas mental atau psikis yang berlangsung dalam suatu interaksi aktif dengan lingkungannya, yang menghasilkan perubahan-perubahan pengetahuan, pengalaman, keterampilan dan nilai sikap.

Menurut Abdurrahman (1999) dalam Jihad (2008: 14), hasil belajar merupakan keluaran (outputs) dari suatu sistem pemrosesan masukan (input). Masukan dari sitem tersebut berupa bermacam-macam informasi sedangkan keluarannya adalah perbuatan atau kinerja (performance). Masih menurut Jihad (2008: 15) menyatakan bahwa hasil belajar adalah perubahan tingkah laku siswa secara nyata setelah dilakukan proses belajar mengajar yang sesuai dengan tujuan pengajaran. Baik buruknya hasil 
belajar dapat dilihat dari hasil pengukuran yang berupa evaluasi, selain mengukur hasil belajar penilaian dapat juga ditujukan kepada proses pembelajaran, yaitu untuk mengetahui sejauh mana tingkat kterlibatan siswa dalam proses pembelajaran. Semakin baik proses pembelajaran dan keaktifan siswa dalam mengikuti proses pembelajaran, maka seharusnya hasil belajar yang diperoleh siswa akan semakin tinggi sesuai dengan tujuan yang telah dirumuskan sebelumnya.

Hasil belajar merupakan kulminasi dari suatu proses yang telah dilakukan dalam belajar. Hasil belajar harus menunjukkan suatu perubahan tingkah laku atau perolehan perilaku yang baru dari siswa yang bersifat menetap, fungsional, positif dan disadari (Anitah, 2011: 2.19). Ada berbagai faktor yang dapat mempengaruhi proses dan hasil belajar siswa di sekolah yang secara garis bessarnya dapat dibagi dalam dua bagian yaitu faktor internal dan faktor eksternal siswa. (Sabri, 1995 : 59). Faktor-faktor yang berasal dari luar diri siswa (eksternal) terdiri dari faktor lingkungan dan faktor instrumental. Sedangkan faktor-faktor yang berasal dari dalam diri siswa (internal); adalah berupa faktor fisiologis dan psikologis pada diri siswa.

Melalui uraian para ahli di atas dapat dikatakan bahwa hasil belajar merupakan keluaran (outputs) yang diperoleh pada titik puncak/ kulminasi dari proses belajar mengajar. Dalam proses belajar ini di dalamnya terdapat proses pemasukan berupa informasi. Outputs yang diperoleh berupa perubahan tingkah laku atau perilaku yang baru yang bersifat positif dan disadari. Kualitas hasil belajar dapat dilihat dari hasil pengukuran berupa evaluasi

\section{Hakikat Ilmu Pengetahuan Sosial}

Istilah Ilmu Pengetahuan Sosial, disingkat IPS, menurut Supriya (2009:19) merupakan nama mata pelajaran di tingkat sekolah dasar dan menengah atau nama program studi di perguruan tinggi identik dengan istilah "social studies". Pemikiran mengenai konsep Ilmu Pengetahuan Sosial di Indonesia banyak dipengaruhi oleh pemikiran "sosial studies" di 
Amerika Serikat. Pilar historis-epistemologis, "Sosial Studies" pertama kali disampaikan oleh Edgar Bruce Wesley bahwa studi sosial adalah ilmu-ilmu yang disederhanakan untuk tujuan pendidikan (Barr, Bart dan Shermis, 1977: 1-2 dalam Winaputra 2010: 1.3).

Konsep IPS masuk ke dalam dunia pendidikan di Indonesia pada tahun 1972 - 1973, yakni dalam kurikulum IPS di Indonesia, jenjang pendidikan SD dan SMP, pendidikan IPS dilakukan secara terpadu, sementara pada jenjang SMA, pendidikan IPS sudah mulai di partisi menjadi beberapa bidang kajian, yaitu sejarah, ekonomi, sosiologi dan geografi. Pada kurikulum 1994 ditambah dengan bidang kajian tata negara dan antropologi. Dalam penelitian ini pendidikan IPS di SMA digunakan istilah bidang studi IPS dan mengacu pada kurikulum yang berlaku di SMA saat ini yaitu meliputi mata pelajaran sejarah, ekonomi, sosiologi dan geografi. Sedangkan dalam kurikulum KTSP tahun 2006 IPS di SMK adalah terpadu (Wahab, 2008: 2.19). Kurikulum IPS tahun 2006 bertujuan agar peserta didik memiliki kemampuan sebagai berikut .

1) Mengenal konsep-konsep yang berkaitan dengan kehidupan masyarakat dan lingkungan.

2) Memiliki kemampuan dasar untuk berpikir logis dan kritis, rasa ingin tahu, memecahkan masalah, dan keterampilan dalam kehidupan sosial.

3) Memiliki komitmen dan kesadaran terhadap nilai-nilai sosial dan kemanusiaan.

4) Memiliki kemampuan berkomunikasi, bekerja sama dan berkompetisi dalam masyarakat yan majemuk, di tingkat lokal, nasional, dan global (Sardiyo, 2009:1.26).

Menurut Puskur (2001:9) IPS adalah suatu bahan kajian terpadu yang merupakan penyederhanaan, adaptasi, seleksi dan modifikasi diorganisasikan dari konsep-konsep ketrampilan-ketrampilan Sejarah, Geografi, Sosiologi, Antropologi, dan Ekonomi. Istilah IPS di sekolah dasar merupakan nama mata pelajaran yang berdiri sendiri sebagai 
integrasi dari sejumlah konsep disiplin ilmu sosial, humaniora, sains bahkan berbagai isu dan masalah sosial kehidupan. Materi IPS untuk jenjang sekolah dasar tidak terlihat aspek disiplin ilmu karena lebih dipentingkan adalah dimensi pedagogik dan psikologis serta karakteristik kemampuan berpikir peserta didik yang bersifat holistik.

Berdasarkan pengertian hasil belajar IPS, disimpulkan bahwa hasil belajar adalah kemampuan-kemampuan yang dimiliki peserta didik setelah menerima pengalaman belajarnya dalam penyederhanaan, adaptasi, seleksi dan modifikasi diorganisasikan dari konsep-konsep ketrampilanketrampilan Sejarah, Geografi, Sosiologi, Antropologi, dan Ekonomi. kemampuan-kemampuan tersebut mencakup aspek kognitif, afektif, dan psikomotorik.

\section{B. Metode Demonstrasi}

Menurut Syah (2000:22) metode demonstrasi adalah metode mengajar dengan cara memperagakan barang, kejadian, aturan, dan urutan melakukan suatu kegiatan baik secara langsung maupun melalui penggunaan media pengajaran yang relevan dengan pokok bahasan atau materi yang sedang disajikan.

Menurut Djamarah, (2000:2) metode demonstrasi adalah metode yang digunakan untuk memperlihatkan sesuatu proses atau cara kerja suatu benda yang berkenaan dengan bahan bahan pelajaran. Selanjutnya menurut Syaiful (2008:210) metode demonstrasi ini lebih sesuai untuk mengajarkan pelajaran yang merupakan suatu proses maupun hal-hal yang bersifat rutin. Dengan metode demonstrasi peserta didik berkesempatan mengembangkan kemampuan mengamati segala benda yang sedang terlibat dalam proses pembelajaran serta dapat mengambil kesimpulan-kesimpulan yang diharapkan.

Menurut Sri Anitah (2014:5.25) menjelaskan bahwa metode demonstrasi semata-mata digunakan hanya untuk :

1. Mengkongkritkan suatu konsep atau prosedur yang abstrak. 
2. Mengajarkan bagaimana berbuat atau menggunakan prosedur secara tepat.

3. Meyakinkan bahwa alat dan prosedur tersebut bisa digunakan.

4. Membangkitkan minat menggunakan alat prosedur.

Karakteristik metode demonstrasi pada dasarnya untuk menyampaikan pembelajaran pada siswa dalam penguasaan proses objek tertentu. Dalam pelaksanaan metode mengajar demonstrasi selain guru yang akan menjadi model, juga dapat mendatangkan nara sumber yang akan mendemonstrasikan objek materi pelajaran. Sedangkan tujuan pengajaran mengguakan metode demonstrasi adalah untuk memperlihatkan proses terjadinya suatu peristiwa sesuai materi ajar, cara pencapaiannya dan kemudahan untuk dipahami oleh siswa dalam pengajaran kelas. Manfaat metode demonstrasi.

Manfaat psikologis metode demonstrasi adalah :

1. Perhatian siswa dapat lebih dipusatkan.

2. Proses belajar siswa lebih terarah pada materi yang sedang dipelajari.

3. Pengalaman dan kesan sebagai hasil pembelajaran lebih melekat pada dirisiswa.

Menggunakan metode demonstrasi memiliki keunggulan sebagai berikut

1. Perhatian siswa dapat dipusatkan pada hal-hal yang dianggap penting oleh guru sehingga yang penting itu dapat diamati secara teliti.

2. Siswa dapat memehami bahan pelajaran sesuai dengan objek yang sebenarnya

3. Dapat mengembangkan rasa ingin tahu siswa.

4. Dapat melakukan pekerjaan berdasarkan proses yang sistimatis.

5. Ekonomis dalam jam pelajaran di sekolah dan ekonomi dalam waktu yang panjang dapat diperlihatkan melalui demonstrasi dengan waktu yang pendek.

6. Dapat mengurangi kesalahan-kesalahan bila dibandingkan dengan hanya membaca atau mendengarkan, karena murid mendapatkan gambaran yang jelas dari hasil pengamatannya. 
7. Beberapa persoalan yang menimbulkan pertanyaan atau keraguan dapat diperjelas waktu proses demonstrasi.

Kelemahan metode demonstrasi :

1. Hanya dapat menimbulkan cara berfikir yang kongkrit saja.

2. Jika jumlah siswa banyak dan posisi siswa tidak diatur maka demonstrasi tidak efektif.

3. Bergantung pada alat bantu yang sebenarnya.

4. Sering terjadi siswa kurang berani dalam mencoba atau melakukan praktik yang didemonstrasikan .

5. Tidak semua hal dapat didemonstrasikan di kelas. (Anitah, :5.25).

Jadi dari berbagai penjelasan di atas dapat disimpulkan bahwa Metode Demonstrasi merupakan metode mengajar yang menyajikan bahan pelajaran dengan mempertunjukkan secara langsung objek atau cara melakukan sesuatu sehingga dapat mempelajarinya dengan proses

\section{Media Gambar}

Media adalah perantara atau pengantar pesan dari pengirim sumber pesan kepada penerima pesan secara terminologi yang telah memperluas kemampuan manuasia untuk merasakan atau mendengar. Menurut Hamalik (2013:114) media adalah alat,metode dan teknik yang digunakan dalam rangka mengaktifkan komunikasi dan interaksi guru dan peserta didik dalam proses pembelajaran. Bahwa media pembelajaran merupakan sarana atau bentuk komunikasi yang merupakan wadah informasi.

Ada beberapa macam media pembelajaran antara lain:

1. Media visual yang tidak diproyeksikan ( gambar, ilustrasi, karikatur, poster, bagan, diagram, grafik dan peta )

2. Media audio ( wawancara, berita, radiao, warta berita, drama radio

3. diskusi dan seminar).

4. Media visual yang diproyeksikan ( Over Head, Projector, slide proyektor)

5. Media cetak ( buku pelajaran, modul, majalah, surat kabar ). 
Media gambar adalah suatu media visual yang hanya dapat dilihat saja, akan tetapi tidak mengandung unsur suara atau audio. Media realita adalah suatu media mengandung benda-benda yang nyata saat digunakan dalam pembelajaran. Misal contohnya : Hewan dan Tumbuh-tumbuhan yang hidup. Selanjutya Hamalik (1986:43) berpendapat bahwa gambar adalah segala sesuatu yang diwujudkan secara visual dalam bentuk dua dimensi sebagai curahan perasaan atau pikiran.

Sedangkan menurut Sumantri, (2004:178) mengemukakan bahwa secara umum media gambar berfungsi sebagai:

1. Alat bantu untuk mewujudkan situasi belajar mengajar yang efektif.

2. Bagian integral dari keseluruhan situasi mengajar.

3. Meletakkan dasar-dasar konkret yang abstrak sehingga dapat mengurangi pemahaman yang besifat verbalisme

4. Mengembangkan motivasi belajar peserta didik

5. Mempertinggi mutu belajar mengajar.

Dari definisi diatas secara khusus media gambar berfungsi untuk menarik perhatian para peserta didik dalam pembelajaran dikelas. Pada penelitian ini penulis menggunakan dua metode gambar dan media gambar

\section{PELAKSANAAN PENELITIAN PERBAIKAN PEMBELAJARAN}

\section{A. Subjek, Tempat, Waktu Penelitian dan Pihak yang Membantu}

\section{Subjek dan Tempat Penelitian}

Subjek penelitian adalah peserta didik kelas 1 yang berjumlah 31 Peserta didik terdiri dari sebagai 12 Laki- laki dan 19 Perempuan pada mata pelajaran IPS tentang "Peristiwa Penting yang di Alami" Tempat penelitian ini dilakukan di SDN Harjamukti 2 di jalan Pringgondani RT 03 RW 09 Kelurahan Harjamukti Kecamatan Cimanggis Kota Depok.

\section{Waktu Penelitian}

Penelitian ini dilaksanakan mulai hari Kamis tanggal, 14 Januari 2016 diawali dengan prasiklus yang menjadi sumber masalah yang ditemukan, kemudian dilanjutkan perbaikan pembelajaran siklus I pada 
hari Selasa tanggal, 19 Januari 2016. Selanjunta perbaikan pembelajaran siklus 2 pada hari Kamis, tanggal 21 Januari 2016.

\section{Pihak yang Membantu Penelitian}

1. Nentih S.Pd. sebagai supervisor 2

2. Tuti Suparyanti, M.Pd. selaku Kepala Sekolah SD Negeri Harjamukti 2.

\section{B. Desain Prosedur Perbaikan Pembelajaran}

Dalam Penelitian ini dilaksanakan dua siklus yang masing-masing melalui 4 tahapan yaitu tahap perencanaan, pelaksanaan, pengamatan dan refleksi. Adapun pelaksanaan penelitian tersebut dideskripsikan sebagai berikut:

\section{Siklus 1}

\section{a. Persiapan}

1. Perencanaan pelaksanaan pembelajaran yang akan dilaksanakan pada hari, Selasa, tanggal 19 Januari 201614.

2. Guru menyusunan Rencana Pembelajaran IPS dengan Tema Peristiwa Penting yang di Alami

3. Penyusunan metode pembelajaran berupa ceramah dan tanya jawab.

4. Persiapan sumber belajar dan bahan ajar.

5. Penyusunan alat evaluasi pembelajaran atau lembar kerja peserta $\operatorname{didik}(\mathrm{LKS})$

\section{b. Pelaksanaan}

1) Kegiatan awal (10 menit)

a) Guru mengajak peserta didik berdoa, mengisi daftar kelas, menulis hari dan tanggal di papan tulis dan mempersiapkan materi ajar.

b) Guru memperingatkan peserta didik cara duduk yang baik ketika menulis, membaca dan meluruskan barisan meja dan kursi mereka 
c) Guru memberikan motivasi belajar kepada para peserta didik melalui "tepuk semangat" dan menyanyikan Pada Hari Minggu"

d) Guru memperlihatkan contoh peristiwa penting yang pernah dialami diikuti tanya jawab untuk mengetahui kemampuan awal peserta didik tentang apa yang akan dipelajari

e) Guru menyampaikan tujuan pembelajaran setelah pembelajaran peserta didik dapat menyebutkan peristiwa yang pernah di alami

f) Guru menyampaikan topik yang akan dipelajari yaitu "Peristiwa Penting yang di Alami"

g) Guru mengaitkan tofik dengan menyampaikan manfaat konsep tersebut dalam kehidupan sehari-hari

2) Kegiatan inti (40 menit)

a) Guru menyebutkan beberapa Peristiwa Penting yang di Alami

b) Guru meminta peserta didik memperhatikan gambar Peristiwa Penting yang di Alami

c) Guru menjelaskan kejadian yang telah terjadi peristiwa ada yang penting ada yang biasa saja ada yang masih kita ingat ada pula yang sudah kita lupa.

d) Peserta didik dimita menyebutkan dan Peristiwa penting yang alami di rumah dan di lingkungan sekitar atau sekolah

e) Guru meminta beberapa peserta didik untuk maju kedepan menyebutkan peristiwa penting yang alami di rumah dan di lingkungan sekitar atau sekolah

f) Guru memberikan kesempatan peserta didik untuk bertanya

3). Kegiatan Akhir (20 menit)

a) Guru bersama peserta didik menyimpulkan pembelajaran

b) Guru memberikan tugas berupa LKS terkait materi yang baru saja dipelajari.

c) Peserta didik mengerjakan tugas yang diberikan guru. 
d) Guru memberian PR / tugas

e) Menutup pelajaran

\section{c. Pengamatan}

Berdasarkan pengamatan dan observasi saat guru mengajar, yang menjadi permasalahan dalam pembelajaran tersebut adalah:

a) Peserta didik kurang termotivasi dalam pembelajaran.

b) Nilai rata-rata kelas yang diperoleh 67,58 masih dibawah KKM yaitu 70,00, dan peserta didik yang dapat menjawab pertanyaan hanya 15 dari 31 peserta didik.

c) Tanggung jawab peserta didik akan tugas masih rendah, saat diberikan tugas belum dilaksanakan dengan optimal.

d) Media yang digunakan dalam pembelajaran belum maksimal

e) Keterlibatan peserta didik dalam kegiatan pembelajaran masih kurang.

\section{d. Refleksi}

Dari pelaksanaan pembelajaran siklus I, ditemukan kekuatan dan kelemahan dalam tindakan perbaikan pembelajaran diantaranya:

\section{Kekuatan}

a) Pembelajaran lebih efektif dengan metode .

b) Guru sudah melibatkan peserta didik dalam pembelajaran

c) Peserta didik mulai antusias terhadap media yang digunakan

d) Pemahaman materi oleh peserta didik sedikit lebih baik.

\section{Kelemahan}

a) Guru kurang memandu siswa

b) Aktiftas peserta didik belum semua terlibat

c) Belum semua peserta didik melakukan mengerti dengan tugasnya

d) Ruang kelas kurang kondusif karena masih ada anak yang sibuk dengan mengobrol.

e) Pembelajarn masih didominasi peserta didik yang aktif saja. 
f) Perolehan hasil rata-rata kelas masih dibawah KKM yaitu diperoleh 67,58 masih dibawah KKM yaitu 70,00, dan peserta didik yang dapat menjawab pertanyaan hanya 15 dari 31 peserta didik. sehingga perlu dilanjutkan ke siklus berikutnya yaitu siklus II.

\section{Siklus 2}

\section{a. Persiapan}

1) Perencanaan pelaksanaan pembelajaran yang akan dilaksanakan pada hari Kamis, tanggal 21 Januari 2016

2) Pada pertemuan sebelumnya guru menugaskan peserta didik untuk membawa foto keluarga, foto copi akte kelahiran, piagam, mainan waktu kecil, dan rapor Taman Kanak-Kanak

3) Guru menyusunan Rencana Pembelajaran IPS dengan Tema Peristiwa Penting yang di Alami

4) Penyusunan metode pembelajaran berupa ceramah dan tanya jawab.

5) Persiapan sumber belajar dan bahan ajar.

6) Penyusunan alat evaluasi pembelajaran atau lembar kerja peserta didik (LKS)

\section{b. Pelaksanaan}

1) Kegiatan awal (10 menit)

a) Guru mengajak peserta didik berdoa, mengisi daftar kelas, menulis hari dan tanggal di papan tulis dan mempersiapkan materi ajar.

b) Guru memperingatkan peserta didik cara duduk yang baik ketika menulis, membaca dan meluruskan barisan meja dan kursi mereka

c) Guru memberikan motivasi belajar kepada para peserta didik melalui "tepuk semangat" dan menyanyikan lagu "Pada Hari Minggu" 
d) Guru memperlihatkan contoh peristiwa penting yang pernah dialami diikuti tanya jawab untuk mengetahui kemampuan awal peserta didik tentang apa yang akan dipelajari

e) Guru menyampaikan tujuan pembelajaran setelah pembelajaran peserta didik dapat menyebutkan peristiwa yang pernah di alami

f) Guru menyampaikan topik yang akan dipelajari yaitu "Peristiwa Penting yang di Alami"

g) Guru mengaitkan tofik dengan menyampaikan manfaat konsep tersebut dalam kehidupan sehari-hari

2) Kegiatan inti (40 menit)

a) Guru menyebutkan beberapa Peristiwa Penting yang di Alami

b) Guru menjelaskan kejadian yang telah terjadi peristiwa ada yang penting ada yang biasa saja ada yang masih kita ingat ada pula yang sudah kita lupa dengan perlihat gambar beberapa peristiwa penting

c) Guru meminta peserta didik memperhatikan gambar Peristiwa Penting yang di Alami

d) Peserta didik diminta menyebutkan dan Peristiwa penting yang alami di rumah dan di lingkungan sekitar atau sekolah dengan media yang mereka bawa

e) Guru memberikan penguatan kepada peserta didik

f) Guru memberikan kesempatan peserta didik untuk bertanya

3). Kegiatan Akhir (20 menit)

a) Guru bersama peserta didik menyimpulkan pembelajaran

b) Guru memberikan tugas berupa LKS terkait materi yang baru saja dipelajari.

c) Peserta didik mengerjakan tugas yang diberikan guru.

d) Guru memberian PR / tugas

e) Menutup pelajaran

\section{c. Pengamatan}


Peneliti melakukan pengamatan terhadap aktivitas peserta didik dalam mengikuti perbaikan pembelajaran dengan metode demonstrasi. Hasil pengamatan ternyata ada perubahan yang sangat berbeda karena peserta didik menjadi aktif, antusias, dan mengerti dengan jelas materi yang dipelajari. Hal itu berpengaruh dari hasil belajar yang meningkat dari Siklus I (nilai rerata 67,58) ke Siklus II (nilai rerata 88,55). Hal ini dikarena

\section{d. Refleksi}

Dalam melakukan refleksi perbaikan pembelajaran, penulis dan teman sejawat mencatat beberapa hal yang sangat berpengaruh pada penerapan metode demonstrasi melalui media gambar yaitu:

1) Dengan menggunakan metode demonstrasi, peserta didik mendapatkan suasan baru, sehingga dapat menghindari kebosanan dalam proses pembelajaran.

2) Dengan metode demonstrasi, dapat membiasakan peserta didik untuk berkomunikasi aktif dalam bertukar fikiran dengan teman.

3) metode demonstrasi, peserta didik diajarkan untuk mandiri, dan memiliki rasa setia kawan yang tinggi.

4) Dengan metode demonstrasi pada perbaikan pembelajaran pada siklus II ini hasil nila rerata peserta didik sebesar 88,55 dan 28 daris 31 peserta didik (93.5\%)) yang mendapat nilai di atas KKM. Sedangkan Hasil pengamatan didapat data peserta didik yang dapat menjawab pertanyaan guru dengan benar sebanyak 28dari 31 peserta didik atau sebesar $(90.32 \%)$

5) Dengan metode demonstrasi mendapatkan keuntungan, menambah pengalaman dan kepercayaan diri, peserta didik Pada akhirnya kualitas dan hasil belajar semakin membaik, sehingga tidak dilanjutkan dengan siklus berikutnya.

\section{Teknik Analisis Data}


Data yang telah dikumpulkan pada setiap kegiatan observasi dari pelaksanaan siklus penelitian dianalisissecara deskriptif dengan menggunakan teknik presentase untuk melihat kecenderungan yang terjadi dalam kegiatan pembelajaran mata pelajaran IPS.

Dalam pelaksanaan penelitian ini membutuhkan dua siklus perbaikan untuk mata pelajaran matematika. Pada proses perbaikan pembelajaran yang peneliti lakukan adalah melalui tiga tahapan, yaitu diantaranya adalah : perencanaan, pelaksanaan, pengamatan dan refleksi.

Langkah-langkah dalam teknik analisis data yang dilakukan adalah sebagai berikut:

1. Melaksanakan kegiatan pembelajaran, yang terdiri dari kegiatan prasiklus, siklus 1, dan siklus 2 .

2. Mengumpulkan dan menganalisis nilai evaluasi pembelajaran dari tiap siklus.

3. Mendiskripsikan dan membandingkan nilai evaluasi dari tiap siklus.

4. Menentukan tingkat keberhasilan dari hasil evaluasi yang ditempuh dalam proses pembelajaran.

5. Tes, yang digunakan untuk mendapatkan data tentang hasil belajar peserta didik.

6. Observasi, yang digunakan untuk mengumpulkan data tentang perkembangan keaktifan peserta didik dalam proses kegiatan belajar mengajar dengan menggunakan metode demonstrasi.

7. Diskusi dengan teman sejawat tentang keberhasilan dan kekurangan/kelemahan dalam pelaksanaan pembelajaran melalui metode pembelajaran diskusi dan tanya jawab dan merefleksikan hasil setiap siklus untuk perbaikan-perbaikan aktivitas dan praktek pembelajaran yang akan datang.

\section{HASIL PENELITIAN DAN PEMBAHASAN}

A. Deskripsi Hasil Penelitian Perbaikan Pembelajaran 
Dalam pelaksanaan penelitian, peneliti telah dibantu oleh teman sejawat untuk mengamati pelaksanaan pembelajaran. Peneliti berdiskusi dengan supervisor untuk menemukan kekurangan-kekurangan dalam proses pembelajaran. Selain itu, peneliti telah melakukan refleksi atas pembelajaran yang dilakukan untuk melakukan perbaikan-perbaikan pada pembelajaran selanjutnya.

Hasil refleksi pada proses pembelajaran yang perlu diperbaiki adalah sebagai berikut:

1. Rendahnya hasil belajar peserta didik pada mata pelajaran IPS.

2. Peserta didik kesulitan dalam menyelesaikan soal-soal latihan.

3. Peserta didik kurang aktif dalam proses pembelajaran mata pelajaran IPS

4. Kurang motivasi peserta didik terhadap mata pelajaran IPS.

\section{Pra Siklus}

Dalam pelaksanaan pembelajaran pra siklus dengan KKM 70 di SDN Harjamukti 2 Kecamatan Cimanggis Kota Depok kelas 1 Mata Pelajaran IPS tentang "Peristiwa Penting yang Dialami” dari jumlah 31 peserta didik diperoleh hasil rerata peserta didik 55,81 dengan perincin data sebagai berikut jumlah nilai keseluruhan 1640, nilai tertinggi 100, dan nilai terendah 20, 14 orang peserta didik mencapai KKM atau $45.16 \%$ sedangkan yang belum mencapai KKM berjumlah 17 peserta didik atau $54.84 \%$. Sedangkan mlalui pengamatan peserta didik yang dapat menjawab pertanyaan guru hanya ada 14 peserta didik, atau sebesar $45.16 \%$ sedangkan yang tidak dapat pertanyaan guru terdapat 17 orang peserta didik atau 54.83\%. Dalam kegiatan pembelajaran pada pra siklus ini sangatlah kurang memuaskan.Hal ini di sebabkan kurangnya minat dan motivasi sehingga peserta didik sulit memahami materi pelajararan IPS.

\section{Siklus 1}

Dalam pelaksanaan pembelajaran siklus 1 di SDN Harjamukti 2 Kecamatan Cimanggis Kota Depok kelas 1 Mata Pelajaran IPS tentang "Peristiwa Penting yang Dialami” dengan KKM 70 dari jumlah 31 peserta didik diperoleh hasil rerata peserta didik 67,58 dengan perincin sebagai 
berikut jumlah nilai keseluruhan 2095, nilai tertinggi 100, dan nilai terendah 20, peserta didik mencapai KKM berjumlah 16 atau 51.61\%, sedangkan yang belum mencapai KKM berjumlah 15 peserta didik atau 48.39\%. Melalui data pengamatan peserta didik yang dapat menjawab pertanyaan guru hanya ada 15 orang peserta didik atau $48.39 \%$ sedangkan yang tidak dapat pertanyaan guru terdapat 16 peserta didik atau sebesar $51.61 \%$

Dalam kegiatan pembelajaran pada siklus 1 ini sedikit ada peningkatan dalam penilaian hasil belajar hal ini di karenakan menggunakan media dan metode yang digunakan guru tetapi nilai rerata peserta didik belum mencapai KKM hal ini dapat dilihat dari tabel 4.

\section{Siklus 2}

Dalam pelaksanaan pembelajaran siklus 2 di SDN Harjamukti 2 Kecamatan Cimanggis Kota Depok kelas 1 Mata Pelajaran IPS tentang "Peristiwa Penting yang Dialami" dengan KKM 70 dari jumlah 31 peserta didik diperoleh hasil rerata peserta didik 88,55 dengan perincin sebagai berikut jumlah nilai keseluruhan 2745, nilai tertinggi 100, dan nilai terendah 65 , peserta didik mencapai KKM berjumlah 29 orang atau $93.5 \%$ sedangkan yang belum mencapai KKM berjumlah 2 peserta didik atau atau $6.5 \%$. Melalui data pengamatan peserta didik yang dapat menjawab pertanyaan guru berjumlah 28 orang peserta didik atau $90.32 \%$ sedangkan yang tidak dapat pertanyaan guru terdapat 3 orang peserta didik atau $9.68 \%$.

Berikut ini hasil rekapitulasi data nilai dan hasil pengamatan setiap siklus peserta didik pada mata pelajaran IPS di SDN Harjamukti 2 Kecamatan Cimanggis Kota Depok kelas 1 dalam bentuk tabel.

Tabel 1

Rekapitulisasi Data Hasil Belajar Pada Pra Siklus, Siklus 1, Siklus 2

\begin{tabular}{|c|l|c|c|c|c|}
\hline No & Nama & L/P & Pra Siklus & Siklus 1 & Siklus 2 \\
\hline 1. & Adinda Nurul Fatimah & P & 20 & 20 & 65 \\
\hline 2. & Ahmad Fauzan Abdilah & L & 40 & 55 & 75 \\
\hline 3. & Aldy Andika & L & 40 & 45 & 70 \\
\hline
\end{tabular}




\begin{tabular}{|c|c|c|c|c|c|}
\hline 4. & Audry Cantika & $\mathrm{P}$ & 30 & 45 & 80 \\
\hline 5. & Aulia Qurrota A’Yuna & $\mathrm{P}$ & 100 & 100 & 100 \\
\hline 6. & Audrey Hana Maritzateriza & $\mathrm{P}$ & 20 & 20 & 65 \\
\hline 7. & Danisa Salsa Nabila & $\mathrm{P}$ & 30 & 45 & 100 \\
\hline 8. & Evrida Lutfiani & $\mathrm{P}$ & 70 & 75 & 80 \\
\hline 9. & Fasya Zayid Ramadhan & $\mathrm{L}$ & 40 & 55 & 95 \\
\hline 10. & Fatiha Rizkina & $\mathrm{P}$ & 80 & 100 & 100 \\
\hline 11. & Febbry Atasya Putri & $\mathrm{P}$ & 30 & 50 & 90 \\
\hline 12. & Giattika Putri Permata & $\mathrm{P}$ & 70 & 80 & 100 \\
\hline 13. & Gibran Fauzi & $\mathrm{L}$ & 40 & 70 & 90 \\
\hline 14. & Jidan Saputra & $\mathrm{L}$ & 60 & 75 & 85 \\
\hline 15. & Karisa Fitri & $\mathrm{P}$ & 80 & 100 & 100 \\
\hline 16. & Khalila Ibtisam Maulia & $\mathrm{P}$ & 30 & 45 & 80 \\
\hline 17. & Muhamad Alpin Kurniawan & $\mathrm{L}$ & 40 & 55 & 80 \\
\hline 18. & Melviani Lutfiah & $\mathrm{P}$ & 70 & 80 & 100 \\
\hline 19. & $\begin{array}{l}\text { Michaella Resina Aulia } \\
\text { Rahmadany }\end{array}$ & $\mathrm{P}$ & 80 & 90 & 100 \\
\hline 20. & Miftahunnisya & $\mathrm{P}$ & 100 & 100 & 100 \\
\hline 21. & Muhamad Aldino Sebayang & $\mathrm{L}$ & 50 & 60 & 80 \\
\hline 22. & Muhamad Fais Pratama & $\mathrm{L}$ & 80 & 100 & 100 \\
\hline 23. & Muhammad Arga Syawaludin & $\mathrm{L}$ & 40 & 55 & 80 \\
\hline 24. & Nabilah Nuraizah & $\mathrm{P}$ & 30 & 40 & 75 \\
\hline 25. & Nasya Aulia Anggraeni & $\mathrm{P}$ & 30 & 45 & 75 \\
\hline 26. & Nizar Mukhafidin & $\mathrm{L}$ & 70 & 75 & 100 \\
\hline 27. & Fadil Dwi Gulam & $\mathrm{L}$ & 80 & 95 & 100 \\
\hline 28. & Raihan Al Shabah & $\mathrm{L}$ & 50 & 60 & 80 \\
\hline 29. & Reyya Dewi Putri & $\mathrm{P}$ & 70 & 80 & 100 \\
\hline 30. & Siti Anjani & $\mathrm{P}$ & 80 & 90 & 100 \\
\hline 31. & Zahra Tulsifa & $\mathrm{P}$ & 80 & 90 & 100 \\
\hline \multicolumn{3}{|c|}{ Jumlah Nilai } & 1640 & 2095 & 2745 \\
\hline \multicolumn{3}{|c|}{ Nilai tertinggi } & 100 & 100 & 100 \\
\hline \multicolumn{3}{|c|}{ Nilai terendah } & 20 & 20 & 65 \\
\hline \multicolumn{3}{|c|}{ Nilai Rata - rata } & 55,81 & 67,58 & 88,55 \\
\hline \multicolumn{3}{|c|}{ Tuntas } & $14(45.16 \%)$ & $16(51.61 \%)$ & $28(93.5 \%)$ \\
\hline \multicolumn{3}{|c|}{ Tidak Tuntas } & 17. $(54.84 \%)$ & $15(48.39 \%)$ & $2(6.5 \%)$ \\
\hline
\end{tabular}

Tabel 9

Data Rekapitulisasi Pengamatan Hasil Belajar Pra Siklus, Siklus 1, Siklus 2

\begin{tabular}{|c|l|c|c|c|c|c|c|c|}
\hline \multirow{2}{*}{ No } & \multirow{2}{*}{ NAMA } & & \multicolumn{2}{c|}{ Prasiklus } & \multicolumn{2}{c|}{ Siklus 1 } & \multicolumn{2}{c|}{ Siklus 2 } \\
\cline { 3 - 9 } & & & M & TM & M & TM & M & TM \\
\hline 1 & Adinda Nurul Fatimah & P & & $\sqrt{ }$ & & $\sqrt{ }$ & & $\sqrt{ }$ \\
\hline 2 & Ahmad Fauzan Abdilah & L & & $\sqrt{ }$ & & $\sqrt{ }$ & $\sqrt{ }$ & \\
\hline 3 & Aldy Andika & L & $\sqrt{ }$ & & $\sqrt{ }$ & & $\sqrt{ }$ & \\
\hline
\end{tabular}




\begin{tabular}{|c|c|c|c|c|c|c|c|c|}
\hline 4 & Audry Cantika & $\mathrm{P}$ & $\sqrt{ }$ & & $\sqrt{ }$ & & $\sqrt{ }$ & \\
\hline 5 & Aulia Qurrota A'Yuna & $\mathrm{P}$ & & $\sqrt{ }$ & $\sqrt{ }$ & & $\sqrt{ }$ & \\
\hline 6 & $\begin{array}{l}\text { Audrey Hana } \\
\text { Maritzateriza }\end{array}$ & $\mathrm{P}$ & $\sqrt{ }$ & & $\sqrt{ }$ & & $\sqrt{ }$ & \\
\hline 7 & Danisa Salsa Nabila & $\mathrm{P}$ & & $\sqrt{ }$ & & $\sqrt{ }$ & $\sqrt{ }$ & \\
\hline 8 & Evrida Lutfiani & $\mathrm{P}$ & & $\sqrt{ }$ & & $\sqrt{ }$ & $\sqrt{ }$ & \\
\hline 9 & Fasya Zayid Ramadhan & $\mathrm{L}$ & & $\sqrt{ }$ & $\sqrt{ }$ & & $\sqrt{ }$ & \\
\hline 10 & Fatiha Rizkina & $\mathrm{P}$ & & $\sqrt{ }$ & $\sqrt{ }$ & $\sqrt{ }$ & $\sqrt{ }$ & \\
\hline 11 & Febbry Atasya Putri & $\mathrm{P}$ & $\sqrt{ }$ & & $\sqrt{ }$ & & $\sqrt{ }$ & \\
\hline 12 & Giattika Putri Permata & $\mathrm{P}$ & & $\sqrt{ }$ & & $\sqrt{ }$ & & $\sqrt{ }$ \\
\hline 13 & Gibran Fauzi & $\mathrm{L}$ & & $\sqrt{ }$ & . & $\sqrt{ }$ & $\sqrt{ }$ & \\
\hline 14 & Jidan Saputra & $\mathrm{L}$ & $\sqrt{ }$ & & $\sqrt{ }$ & & $\sqrt{ }$ & \\
\hline 15 & Karisa Fitri & $\mathrm{P}$ & $\sqrt{ }$ & & $\sqrt{ }$ & & $\sqrt{ }$ & \\
\hline 16 & Khalila Ibtisam Maulia & $\mathrm{P}$ & $\sqrt{ }$ & & & $\sqrt{ }$ & & $\sqrt{ }$ \\
\hline 17 & $\begin{array}{l}\text { Muhamad Alpin } \\
\text { Kurniawan }\end{array}$ & $\mathrm{L}$ & $\sqrt{ }$ & & $\sqrt{ }$ & & $\sqrt{ }$ & \\
\hline 18 & Melviani Lutfiah & $\mathrm{P}$ & $\sqrt{ }$ & & $\sqrt{ }$ & & $\sqrt{ }$ & \\
\hline 19 & $\begin{array}{l}\text { Michaella Resina Aulia } \\
\text { Rahmadany }\end{array}$ & $\mathrm{P}$ & & $\sqrt{ }$ & $\sqrt{ }$ & & $\sqrt{ }$ & \\
\hline 20 & Miftahunnisya & $\mathrm{P}$ & & $\sqrt{ }$ & & $\sqrt{ }$ & $\sqrt{ }$ & \\
\hline 21 & $\begin{array}{l}\text { Muhamad Aldino } \\
\text { Sebayang }\end{array}$ & $\mathrm{L}$ & $\sqrt{ }$ & & $\sqrt{ }$ & & $\sqrt{ }$ & \\
\hline 22 & Muhamad Fais Pratama & $\mathrm{L}$ & & $\sqrt{ }$ & & $\sqrt{ }$ & $\sqrt{ }$ & \\
\hline 23 & $\begin{array}{l}\text { Muhammad Arga } \\
\text { Syawaludin }\end{array}$ & $\mathrm{L}$ & & $\sqrt{ }$ & $\sqrt{ }$ & $\sqrt{ }$ & $\sqrt{ }$ & \\
\hline 24 & Nabilah Nuraizah & $\mathrm{P}$ & & $\sqrt{ }$ & $\sqrt{ }$ & $\sqrt{ }$ & $\sqrt{ }$ & \\
\hline 25 & Nasya Aulia Anggraeni & $\mathrm{P}$ & & $\sqrt{ }$ & & $\sqrt{ }$ & $\sqrt{ }$ & \\
\hline 26 & Nizar Mukhafidin & $\mathrm{L}$ & & $\sqrt{ }$ & & $\sqrt{ }$ & $\sqrt{ }$ & \\
\hline 27 & Fadil Dwi Gulam & $\mathrm{L}$ & $\sqrt{ }$ & & $\sqrt{ }$ & & $\sqrt{ }$ & \\
\hline 28 & Raihan Al Shabah & $\mathrm{L}$ & $\sqrt{ }$ & & $\sqrt{ }$ & & $\sqrt{ }$ & \\
\hline 29 & Reyya Dewi Putri & $\mathrm{P}$ & $\sqrt{ }$ & & $\sqrt{ }$ & $\sqrt{ }$ & $\sqrt{ }$ & \\
\hline 30 & Siti Anjani & $\mathrm{P}$ & $\sqrt{ }$ & & $\sqrt{ }$ & & $\sqrt{ }$ & \\
\hline 31 & Zahra Tulsifa & $\mathrm{P}$ & & $\sqrt{ }$ & & $\sqrt{ }$ & $\sqrt{ }$ & \\
\hline \multicolumn{3}{|c|}{ Jumlah } & 14 & 17 & 15 & 16 & 28 & 3 \\
\hline \multicolumn{3}{|c|}{ Prosentase } & $45.16 \%$ & $54.83 \%$ & $48.39 \%$ & $51.61 \%$ & $90.32 \%$ & $9,68 \%$ \\
\hline
\end{tabular}

B. Pembahasan Hasil Penelitian Perbaikan Pembelajaran

Dalam pelaksanaan pembelajaran pra siklus dengan KKM 70 di SDN Harjamukti 2 Kecamatan Cimanggis Kota Depok kelas 1 Mata Pelajaran IPS tentang "Peristiwa Penting yang Dialami" dari jumlah 31 peserta didik diperoleh hasil rerata peserta didik 55,81 dengan perincin data sebagai berikut jumlah nilai keseluruhan 1640, nilai tertinggi 100, dan nilai terendah 20, 14 orang peserta didik mencapai KKM atau $45.16 \%$ sedangkan yang 
belum mencapai KKM berjumlah 17 peserta didik atau $54.84 \%$. Sedangkan mlalui pengamatan peserta didik yang dapat menjawab pertanyaan guru hanya ada 14 peserta didik, atau sebesar $45.16 \%$ sedangkan yang tidak dapat pertanyaan guru terdapat 17 orang peserta didik atau $54.83 \%$. Dalam kegiatan pembelajaran pada pra siklus ini sangatlah kurang memuaskan.

Pada pembelajaran prasiklus ini nilai rerata pembelajaran IPS di bawah KKM sehingga pretasi belajar masih rendah. Hal berikutnya adalah peserta didik kurang termotivasi dalam pembelajaran, peserta didik menjadi pasif dan tanggung jawab peserta didik terhadap tugas masih rendah. Penyebab faktor tersebut disebababkan karena (1) Guru belum menggunakan media pembelajaran yang sesuai secara maksimal sehingga tidak terciptanya suasana pembelajaran yang kondusif, dan menyenangkan bagi peserta didik. (2) Guru belum menggunakan metode pembelajaran dan teknik pembelajaran yang bervariasi dan efektif (3) Guru kurang memberikan motivasi pada saat pembelajaran berlangsung sehingga peserta didik tidak tertarik pada pelajaran IPA. (4) Guru jarang mengadakan reward dan umpan balik secara langsung selama pembelajaran, sehingga peserta didik tidak aktif.

Pada pelaksanaan pembelajaran siklus 1 di SDN Harjamukti 2 Kecamatan Cimanggis Kota Depok kelas 1 Mata Pelajaran IPS tentang "Peristiwa Penting yang Dialami" dengan KKM 70 dari jumlah 31 peserta didik diperoleh hasil rerata peserta didik 67,58 dengan perincin sebagai berikut jumlah nilai keseluruhan 2095, nilai tertinggi 100, dan nilai terendah 20, peserta didik mencapai KKM berjumlah 16 atau 51.61\%, sedangkan yang belum mencapai KKM berjumlah 15 peserta didik atau $48.39 \%$. Melalui data pengamatan peserta didik yang dapat menjawab pertanyaan guru hanya ada 15 orang peserta didik atau $48.39 \%$ sedangkan yang tidak dapat pertanyaan guru terdapat 16 peserta didik atau sebesar 51.61\%. Walaupun ada ada peningkatan tetapi rerata peserta didik belum sesai KKM

Dengan demikian maka peneliti melakukan penelitian pada siklus 2 . Untuk mengatasi permasalah di siklus 1 maka peneliti melakukan sebagai berikut : 
1. Menggunakan media pembelajaran yang sesuai secara maksimal sehingga tidak terciptanya suasana pembelajaran yang kondusif, dan menyenangkan bagi peserta didik

2. Menggunakan metode pembelajaran dan teknik pembelajaran yang bervariasi dan efektif

3. Memberikan motivasi pada saat pembelajaran berlangsung sehingga peserta didik tidak tertarik pada pelajaran IPA

4. Mengadakan reward dan umpan balik secara langsung selama pembelajaran, sehingga peserta didik tidak aktif.

Dalam pelaksanaan pembelajaran siklus 2 dari jumlah 31 peserta didik diperoleh hasil rerata peserta didik 88,55 dengan perincin sebagai berikut jumlah nilai keseluruhan 2745, nilai tertinggi 100, dan nilai terendah 65 , peserta didik mencapai KKM berjumlah 29 orang atau 93.5\% sedangkan yang belum mencapai KKM berjumlah 2 peserta didik atau atau $6.5 \%$. Melalui data pengamatan peserta didik yang dapat menjawab pertanyaan guru berjumlah 28 orang peserta didik atau $90.32 \%$ sedangkan yang tidak dapat pertanyaan guru terdapat 3 orang peserta didik atau $9.68 \%$.

Maka keberhasilan pembelajaran untuk mata pelajaran IPS peneliti menggunakan media gambar, dalam kegiatan pembelajaran ini peneliti menggunakan media gambar yang membuat para peserta didik antusias, ketika peneliti menggunakan media gambar yang menarik hampir seluruh peserta didik maju ke depan ingin melihat lebih dekat media gambar yang peneliti gunakan meskipun tanpa maju ke depan pun sudah tampak jelas tetapi para peserta didik ingin lebih puas lagi melihatnya setelah peneliti menggunakan media pembelajaran yang menarik yaitu memberikan latihan soal yang sesuai dari materi penjelasan peneliti pada siklus 2 ini yaitu dengan memasangkan gambar, peneliti pun sangat senang sekali karena proses pembelajaran yang dilakukan dalam 2 siklus ini memberikan hasil yang baik, dan peneliti pun menyadari bahwa perlu menggunakan media yang menarik mungkin agar para mendapatkan hasil yang di harapkan dan membuat suasana yang lebih menyenangkan karena untuk tingkatan kelas rendah perlu 
melakukan kelas yang menyenangkan yaitu dengan sebuah permainan sebelum memulai pembelajaran agar para peserta didik pun nantinya dalam penerimaan pembelajaran akan lebih memahami

Peran guru tidak kalah pentingnya dalam menggerakan minat belajar peserta didik.Salah satu yang di gunakan yaitu dengan menyediakan sumber dan media pembelajaran yang tepat dan sesuai serta melibatkan peserta didik dalam proses pembelajaran berlangsung. Mengenal dan sanggup menggunakan metode mengajar adalah kemampuan dasar guru yang paling utama dalam meraih sukses di sekolah.

\section{KESIMPULAN DAN SARAN TINDAK LANJUT}

\section{A. Kesimpulan}

Berdasarkan hasil Penelitian Tindakan Kelas (PTK) melalui aktivitas perbaikan pembelajaran yang telah dilaksanakan mulai dari prasiklus, siklus I sampai dengan siklus II pada mata pelajaran IPA, penulis dapat menarik kesimpulan sebagai berikut :

1. Dalam pelaksanaan pembelajaran prasiklus dengan KKM 70 di SDN Harjamukti 2 Kecamatan Cimanggis Kota Depok kelas 1 Mata Pelajaran IPS tentang "Peristiwa Penting yang Dialami” dari jumlah 31 peserta didik diperoleh hasil rerata peserta didik 55,81 dan peserta didik yang mencapai KKM 14 atau 45.16\% Sedangkan mlalui pengamatan peserta didik yang dapat menjawab pertanyaan guru hanya ada 14 (45.16\%). Siklus 1 hasil rerata peserta didik 67,58 yang belum mencapai KKM berjumlah 15 peserta didik atau 48.39\%. Melalui data pengamatan peserta didik yang dapat menjawab pertanyaan guru hanya ada 15 (48.39\%) Dalam pelaksanaan pembelajaran siklus 2 diperoleh hasil rerata peserta didik 88,55 peserta didik yang mencapai KKM berjumlah 29 orang atau $93.5 \%$ sedangkan data pengamatan peserta didik yang dapat menjawab pertanyaan guru berjumlah 28 orang peserta didik atau $90.32 \%$

2. Dengan demikian penerapan metode demonstrasi melalui Media Gambar telah memberikan pengaruh yang sangat baik dengan meningkatkan 
prestasi belajar dan motivasi peserta didik materi yang disampaikan dimengerti peserta didik, Tanggung jawab peserta didik terhadap tugas tinggi, serta membantu peserta didik untuk terlibat aktif di dalam kelas dan

\section{B. Saran Tindak Lanjut}

Berdasarkan pada kesimpulan diatas ada beberapa hal yang sebaiknya dilakukan guru dalam upaya meningkatkan hasil belajar peserta didik.

1. Motivasi yang kuat sangat dibutuhkan oleh seorang peserta didik sebelum melakukan pembelajaran.

2. Suasana belajar yang aktif di dalam kelas akan memotivasi peserta didik dalam belajar.

3. Penggunaan metode demonstrasi melalui Media Gambar dapat membantu peserta didik untuk lebih cepat memahami konsep materi pelajaran. Dalam hal ini metode demonstrasi dapat menjadi alternatif yang digunakan guru dalam mengajarkan pembelajaran IPS.

4. Memberikan kesempatan kepada peserta didik untuk lebih aktif di kelas, mengeluarkan pendapat untuk menumbuhkan rasa percaya diri serta keberanian anak dalam menjawab pertanyaan

\section{DAFTAR PUSTAKA}

Arsyad, Arsyad, \& Sulfemi, Wahyu Bagja. (2013). Pengaruh Persepsi Guru Tentang Kemampuan Manajerial Kepala Sekolah dan Kecerdasan Emosional Guru Terhadap Kinerja Guru (Studi Kasus Di SMK Muhammadiyah 6 Kabupaten Bogor). Fascho 2 (1), 1-9.

Anitah W, Sri dkk, 2014, Strategi Pembelajaran di SD, Tanggerang Selatan : Universitas Terbuka

Ahmadi, Abu. (2009). Ilmu Sosial Dasar . Jakarta Rineka : Cipta

Asrori, Muhammad, 2009, Penelitian Tindakan Kelas, Bandung : CV Wacana Prima

Barber, Bart dan Shermis, (1977). Publik Talk and Civiv Action : Education for Participation in a Strong Demokracy in Rauner. CIVNet 
Djamarah, (2000), Strategi belajar mengajar, Jakarta:Rineka Cipta

Fajartriani, Tia dan Sulfemi, Wahyu Bagja. (2014). Pengaruh Motivasi Kerja Guru dan Iklim Organisasi Terhadap Kinerja Guru SMA Negeri di Kecamatan Cigudeg. Edutecno. 8 (1), 17-26.

Jihad Asep, Abdul Haris. (2013). Evaluasi Pembelajaran. Yogyakarta: Multi Pressindo

Hamalik, Umar. (2008). Kurikulum dan Pembelajaran. Jakarta : PT Bumi Aksara.

Sumantri, M. Dan Syaodih, N (2006). Perkembangan Peserta Didik. Jakarta: Universitas Terbuka.

Puskur. (2001). Kurikulwn Berbasis Kompetensi, Mata Pelajaran Sains Sekolah. Dasar. Jakarta

Sapriya. (2009). Pendidikan IPS. Bandung: PT Remaja Rosda Karya.

Slameto. (2003), Belajar dan Fakta yang Mempengaruhinya. Jakarta : Rineka Cipta

Sudirman, Sudirman \& Sulfemi, Wahyu Bagja. (2010). Korelasi Antara Konsep Diri Guru dengan Profesionalisme Guru di SMA Negeri 1 Pamijahan Kabupaten Bogor. Edutecno 2 (2), 10-19

Sugiri, Sugiri \& Sulfemi, Wahyu Bagja. (2011). Pendidikan Multi Kultur di Sekolah Berbasis Keagamaan. Edutecno. 3 (2), 11-20.

Sulfemi, Wahyu Bagja. (2009). Modul Pembelajaran Pendidikan Pancasila dan Kewarganegaraar. Bogor : STKIP Muhammadiyah Bogor

Supardi, (2012), Penelitian Tindakan Kelas, Jakarta : Bumi Aksara

Syah, Muhibbin. (2004), Psikologi Pendidikan dengan Pendekatan Baru. Bandung : Remaja Rosdakarya.

Sardiyo, dkk.(2009). Pendidikan IPS di SD. Tanggerang Selatan : UniversitasTerbuka

Sagala, Syaiful. (2008). Konsep dan Makna Pembelajaran. Jakarta : Alfabeta. Sabri, Alisuf. (1995). Psikologi Pendidikan. Jakarta : Pedoman Ilmu Jaya.

Sulfemi, Wahyu Bagja. (2015). Kemampuan Pedagogik Guru. Prosiding Seminar Nasional. STKIP Muhammadiyah Bogor 1. (1). 71-8.

Sulfemi, Wahyu Bagja. (2016). Kompetensi Profesionalisme Guru Indonesia dalam Menghadapi MEA. Prosiding Seminar Nasional STKIP Muhammadiyah Bogor. 1 (1), 62-77. 
Sulfemi, Wahyu Bagja dan Abdul Qodir. (2017). Hubungan Kurikulum 2013 Dengan Motivasi Belajar Peserta Didik Di SMK Pelita Ciampea. Edutecno 17 (2), 1-8.

Sulfemi, Wahyu Bagja dan Lestari, Ayu Hopilatul. (2017). Korelasi Kompetensi Pedagogik Guru dengan Prestasi Belajar Mata Pelajaran IPS Di SMP Muhammadiyah Pamijahan Kabupaten Bogor. Edutecno. 16 (1), 1-16.

Sulfemi, Wahyu Bagja dan Supriyadi, Dede. (2018). Pengaruh Kemampuan Pedagogik Guru dengan Hasil Belajar IPS. Edutecno 17 (1), 1-10.

Sulfemi, Wahyu Bagja. (2018). Hubungan Motivasi Belajar Dengan Hasil Belajar IPS Di SMP Kabupaten Bogor. Edutecno 18 (2), 1-8.

Sulfemi, Wahyu Bagja dan Nurhasanah. (2018). Penggunaan Metode Demontrasi dan Media Audio Visual Dalam Meningkatkan Hasil Belajar Peserta Didik Mata Pelajaran IPS. Jurnal Pendas Mahakam. 3 (2). 151-158.

Sulfemi, Wahyu Bagja dan Hilga Minati. (2018). Meningkatkan Hasil Belajar Peserta Didik Kelas 3 SD Menggunakan Model Picture And Picture dan Media Gambar Seri. JPSD. 4 (2), 228- 242

Sulfemi, Wahyu Bagja dan Setianingsih. (2018), Penggunaan Tames Games Tournament (TGT) Dengan Media Kartu Dalam Meningkatkan Hasil Belajar. Journal of Komodo Science Education (JKSE. 1 (1), 1-14

Sulfemi, Wahyu Bagja. (2018). Pengaruh Disiplin Ibadah Sholat, Lingkungan Sekolah, dan Intelegensi Terhadap Hasil Belajar Peserta Didik Mata Pelajaran Pendidikan Agama Islam. Edukasi: Jurnal Penelitian Pendidikan Agama dan Keagamaan. 16 (2), 166-178

Sulfemi, Wahyu Bagja dan Desmiati, Zulaicha. (2018). Model Pembelajaran Missouri Mathematics Project Berbantu Media Relief Experience dalam Meningkatkan Hasil Belajar Siswa. Jurnal Pendas Mahakam . 3 (3), 232-245.

Sulfemi, Wahyu Bagja. (2018). Manajemen Kurikulum di Sekolah. Bogor : Visi Nusantara Maju.

Sulfemi, Wahyu Bagja. (2019). Modul Pembelajaran Perundang-Undangan Pendidikan. Bogor : STKIP Muhammadiyah Bogor.

Winkel, W.S. (1996). Psikologi Pengajaran, Edisi yang Disempurnakan, Cetakan ke-4 Jakarta :Grasindo.

Winaputra, Udin S. Dkk. (2010). Materi dan Pembelajarn IPS SD. Jakarta : Universitas Terbuka

Wahab, Abdul Azis (2008). Konsep Dasar IPS. Jakarta : Universitas Terbuka Wardhani, IGAK, (2014), Penelitian Tindakan Kelas, Tangerang Selatan : Universitas Terbuka. 
